\title{
The impact of hydrological conditions on salinisation and nitrate concentration in the coastal Velez River aquifer (southern Spain)
}

\author{
Azzurra Lentini $\cdot$ Claus Kohfahl · Jose Benavente • \\ José Luis García-Aróstegui · Inaki Vadillo · \\ Hanno Meyer · Asaf Pekdeger
}

Received: 5 August 2008/Accepted: 26 November 2008

(C) Springer-Verlag 2009

\begin{abstract}
This study reports the impact of hydrological conditions on salinisation and nitrate concentrations of a coastal aquifer located at the Mediterranean Sea, southern Spain. Eighty-two samples of ground- and surface water taken during two extreme hydrological events between 1994 and 1996 at 25 different wells were evaluated with regard to hydrochemistry, focusing on nitrate concentrations and salinisation, which constitute the main hazard of this aquifer. Furthermore, hydrochemical data were analysed by principal component analysis (PCA). Additionally,
\end{abstract}

A. Lentini · C. Kohfahl $(\bowtie) \cdot$ A. Pekdeger

Freie Universität Berlin, Institute of Geological Sciences,

Malteserstr. 74-100, 12249 Berlin, Germany

e-mail: kohfahl@zedat.fu-berlin.de

A. Lentini

e-mail: azzurralentini@gmail.com

A. Pekdeger

e-mail: pekdeger@zedat.fu-berlin.de

J. Benavente

Instituto del Agua de la Universidad de Granada,

Calle Ramón y Cajal no. 4, 18071 Granada, Spain

e-mail: jbenaven@ugr.es

J. L. García-Aróstegui

Instituto Geológico y Minero de España,

Calle Alfonso X El Sabio, 6, 30008 Murcia, Spain

e-mail: j.arostegi@igme.es

I. Vadillo

Departmento de Geología, Facultad de Ciencias,

Universidad de Málaga, 29071 Malaga, Spain

e-mail: vadillo@uma.es

H. Meyer

Alfred Wegener Institute, Telegrafenberg A43,

14473 Potsdam, Germany

e-mail: hmeyer@awi-potsdam.de in 200713 ground- and surface water samples taken at 12 different locations were analysed for stable isotopes of $\mathrm{D} /{ }^{18} \mathrm{O}$, and one sample was analysed for ${ }^{15} \mathrm{~N}$. Since 1993 until present saltwater intrusion was observed only during dry hydrological conditions in 1994; it showed an irregular salinisation pattern probably related to locally elevated hydraulic conductivities. Nitrate concentrations increase significantly during wet hydrologic conditions owing to uptake of nitrate by rising groundwater. Stable isotopes of groundwater reveal an Atlantic origin of the precipitation that recharges the aquifer and a minor amount of groundwater recharge by the water coming from the La Viñuela reservoir, which is used for irrigation over the aquifer. ${ }^{15} \mathrm{~N}$ isotopes point to a considerable input of nitrates derived from organic fertilisers.

Keywords Coastal contamination .

Environmental isotopes · Water resources

\section{Introduction and hydrogeological setting}

Seawater intrusion and nitrate contamination are one of the main hazards of groundwater quality in coastal aquifers with intensive agricultural groundwater exploitation. Seawater intrusion in coastal aquifers has been studied by, among others, Bear et al. (1999), Calvache and PulidoBosch (1997), Paniconi et al. (2001) and Rejani et al. (2008). Nitrate pollution affects many shallow aquifers and is mostly related to intense agricultural fertilisation (Dimopoulos et al. 2003; Weil et al. 1990).

The Velez River aquifer is situated at the Mediterranean coast of southern Spain, some $40 \mathrm{~km}$ east of Malaga (Fig. 1); the outcrop area of the aquifer is $20 \mathrm{~km}^{2}$ and the hydrologic basin $610 \mathrm{~km}^{2}$. The aquifer is made up of 


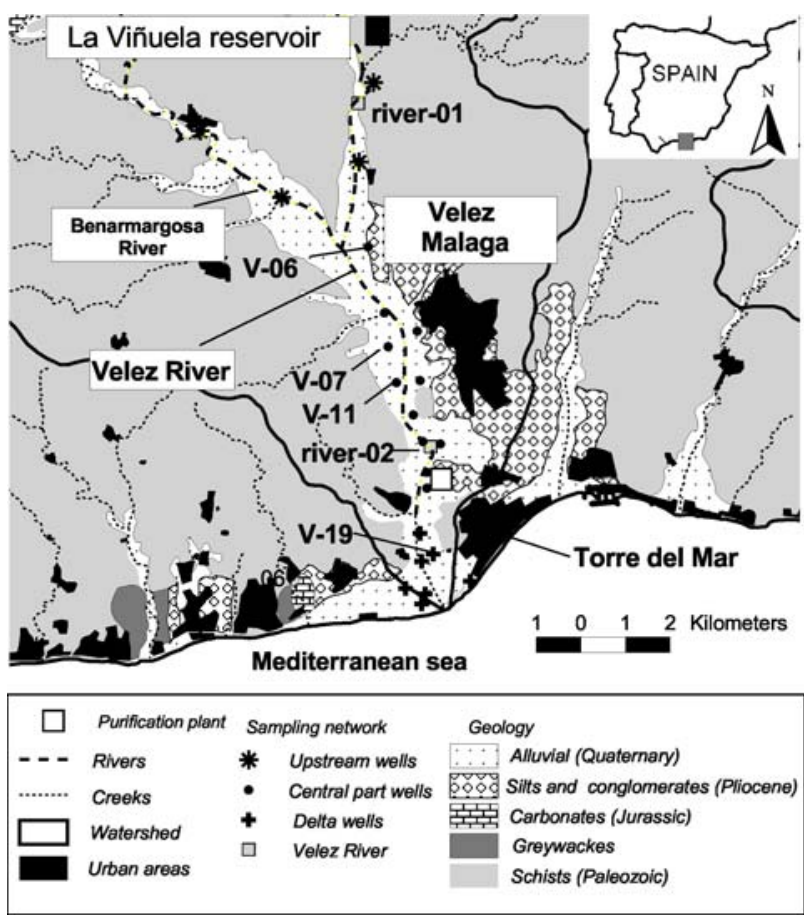

Fig. 1 Study area and sampling network

Quaternary deltaic and alluvial sediments, composed mainly of gravels and sands. The substratum and borders of the aquifer are metapelitic materials from the Internal Zones of the Betic Cordillera as well as postorogenic Pliocene silty clays, all having very low permeability. The average thickness of the permeable detrital formation material is $30 \mathrm{~m}$ and reaches maximums of approximately $60 \mathrm{~m}$ in the central part-confluence of the Velez and Benamargosa rivers-and in the deltaic sector (CHSE 1997). The elevation of the impermeable substratum at $4 \mathrm{~km}$ from the coast considerably reduces the vertical aquifer thickness to $6 \mathrm{~m}$, dividing the aquifer into a fluvial sector upstream and a coastal (deltaic) sector downstream, which can become separate during times of severe drought owing to general piezometric decrease (CHSE 1987; Benavente et al. 2005). This situation is advantageous from a hydrogeological point of view as it inhibits the saltwater wedge from intruding inland.

The hydrological regime of the Velez aquifer is conditioned by the La Viñuela Reservoir, located at the head of the Velez River (Fig. 1), which started to store water in 1989. The climate of the area is Mediterranean with a semiarid trend. The yearly average temperature is $18^{\circ} \mathrm{C}$. The average precipitation over the basin approximates $600 \mathrm{~mm}$ per year, and the main recharge is between October and April. Over the aquifer the average precipitation is slightly less than $500 \mathrm{~mm}$ per year. The annual amount of precipitation may vary considerably. The most important hydrological changes due to climatic conditions and use of

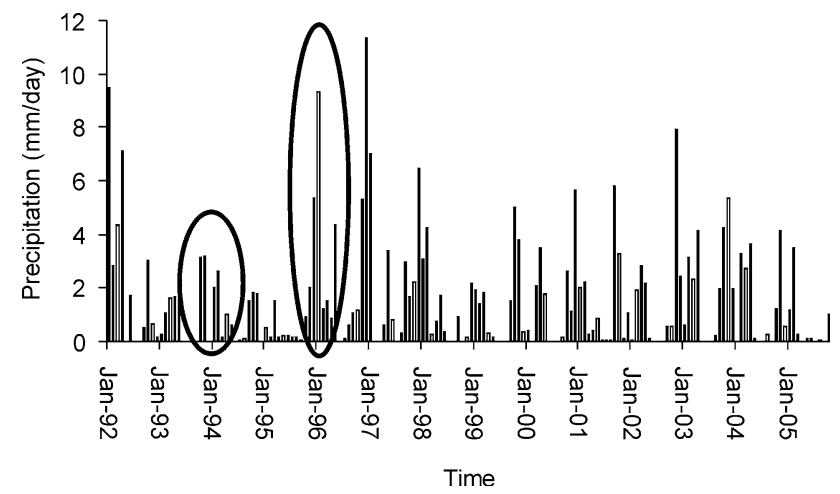

Fig. 2 Monthly averaged daily precipitation in the Velez-Malaga watershed from 1992 to 2004. Data are provided by Confederación Hidrográfica del Sur de España (CHSE), station 0192. Circles selected years

the Viñuela reservoir occurred between 1993 and 1997. As shown in Fig. 2 a severe drought occurred between 1991 and 1995, yet 1994/1995 had a minimum annual rainfall of $143 \mathrm{~mm}$. Extremely high rainfall was recorded in the years 1996-1998 with 986 mm/a in 1996/1997 (CHSE 1997). To investigate the impact of hydrological conditions on salinisation and nitrate concentration we selected the years 1994 and 1996 which provide the best hydrochemical database for these extreme hydrological conditions.

The two main rivers of the basin, Velez River and Benamargosa River, mainly recharge the aquifer (CHSE 1997); both have nearly permanent flow, especially in the upper part of the basin. Downstream of Velez-Malaga, the presence of the threshold in the substratum induces the aquifer to drain to the river channel, and this produces a small, permanent flow up to its mouth. The average and minimum discharge of the Velez River is around 5 and $0.4 \mathrm{~m}^{3} / \mathrm{s}$, respectively (Martin-Vivaldi 1991). The changes in precipitation discussed above are reflected in the discharge as illustrated in Fig. 3. Also here the years 1994 and

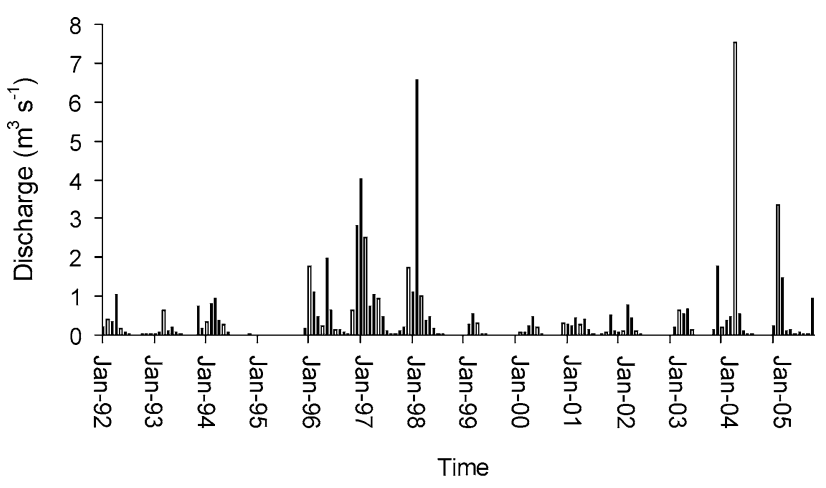

Fig. 3 Monthly averaged discharge rates of the Velez River from 1992 to 2004. Data are provided by Confederación Hidrográfica del Sur de España (CHSE), station 0047 
1996 show low and high discharge rates respectively in spite of the conditioning by the Viñuela Reservoir.

Velez-Malaga, with a population of about 60,000 , and Torre del Mar, with 15,000 inhabitants, are the two main cities in the study area, but the population increases up to 150,000 in the summer months especially in the coastal parts (García-Aróstegui et al. 1996). The economy of this region is based on tourism and profitable agriculture specialising in subtropical-type plantations, mainly avocado trees, and out-of-season crops (Senciales Gonzales 1995).

Since 1997 the diversion of water from the La Viñuela Reservoir to the consumption sectors (supply to VelezMalaga and Torre del Mar, and irrigation of the east bank slopes of the valley) has started to operate effectively. Before this, the human water supply and irrigation activities were mostly based on groundwater resources, and that caused intensive pumping of the aquifer-in more than 400 wells-especially in the summer months, when the surface water resources are at their lowest. At the end of the drought periods this intensive pumping induced problems of overexploitation and, subsequently, contamination of groundwater by salt-water intrusion (García-Aróstegui 1998).

Groundwater withdrawal in the early nineties resulted in significant drops of the piezometric levels and a progressive deterioration of groundwater quality, associated with marine intrusion, as was previously pointed out (GarcíaAróstegui 1998). The high rainfall recorded in the period 1996-1998 improved the quantitative situation considerably, to such an extent that since the end of 1996 the aquifer has no longer presented problems of this type.

Around $400 \mathrm{~kg} / \mathrm{ha}$ of nitrogen are used every year in agriculture, especially from November to April, and in the central sector the concentration of nitrates can reach $300 \mathrm{mg} / \mathrm{l}$ (García-Aróstegui et al. 1996). An increased use of nitrates has been observed in recent years caused by the transformation of the traditional extensive cultivation of sugar cane into the now predominant intensive agriculture (García-Aróstegui et al. 2005; Vadillo et al. 2007). A further problem of pollution is the discharge of urban waste water into the river, which also causes substantial microbiological contamination (Rusch 1993), although this problem has decreased since the sewage treatment plant of the two main towns of the area-Velez-Malaga and Torre del Mar-started to operate in 2006. This plant is located to the south of Velez-Malaga (Fig. 1). The purified water is taken by pipe to the sea, but there is a project for using this water in irrigation after mixing it with water diverted from the La Viñuela reservoir and water pumped from the aquifer, in a proportion of approximately $33 \%$ each.

The aim of this paper is to investigate the impact of changes in hydrological conditions on seawater intrusion and nitrate concentration, which constitute serious hazards for a large number of coastal aquifers.

\section{Methods}

The sampling network of ground- and surface water is compiled in Fig. 1 and Table 1. Evaluation includes isotope data from recent sampling campaigns and data taken during the most extreme hydrologic conditions within the last 15 years represented by 1994 (dry year) and 1996 (wet year).

Groundwater was sampled from operating wells and from piezometers by pumping, using a flow cell. Samples were taken after at least 10 minutes and after constant values of conductivity and redox potential had been established. Temperature, $\mathrm{pH}$, and conductivity were measured in the field. Surface and groundwater samples were filtered immediately after sample retrieval for analysis of cations and anions using $0.45 \mu \mathrm{m}$ membrane filters. The samples were collected in glass bottles, which were carefully filled without any air entrapment for analysis in the laboratory. All collected samples were stored at $4^{\circ} \mathrm{C}$ in polypropylene bottles $(50 \mathrm{ml})$ with watertight caps.

Major cation analysis of pore water was carried out on acidified samples using ICP-AES (Perkin-Elmer AAS 5000), whereas major anions were determined using ion chromatography (Dionex DX-100).

The stable isotopes of water were analysed at the Alfred Wegener Institute (AWI) in Potsdam, using a Finningan MAT Delta-S mass spectrometer equipped with two equilibration units for the online determination of hydrogen and oxygen isotopic composition (Meyer 2000).

The concentrations are given hereafter in $\delta$-units calculated with respect to Vienna standard mean ocean water (VSMOW) expressed in permil.

$\delta(\%)=1,000\left(\frac{R_{\text {sample }}-R_{\text {VSMOW }}}{R_{\text {VSMOW }}}\right)$

where $R_{\text {sample }}$ and $R_{\text {VSMOW }}$ are the isotopic ratio of the sample and of the VSMOW, respectively. The external errors of long-term measurements of hydrogen and oxygen are better than 0.8 and $0.10 \%$ respectively.

The $\delta^{15} \mathrm{~N}$ was determined by isotope ratio mass spectrometry (IRMS).

The principal component analysis (PCA) routine within XLSTAT, Version 7.5.2 (XLSTAT 2008) was used to analyze the groundwater data. Before PCA, each column in Table 2 is converted to a zero mean, unit variance equivalent by subtracting the mean value of the variable and dividing by the standard deviation. This conversion gives each chemical parameter the same magnitude and variance and consequently the same influence in the PCA. Principal components are produced in dimensionless form. 
Table 1 Sampling network for ground and surface water

\begin{tabular}{|c|c|c|c|c|c|}
\hline Site ID & Type & $X(\mathrm{UTM}) \mathrm{m}$ & $Y(\mathrm{UTM}) \mathrm{m}$ & Elevation m (asl) & Depth m \\
\hline Vinuela & Reservoir & 396,680 & $4,080,124$ & 230 & \\
\hline TM & Supply water & 401,687 & $4,066,540$ & 5 & \\
\hline River 01 & & 399,422 & $4,075,920$ & 55 & \\
\hline River 02 & & 400,956 & $4,068,627$ & 16 & \\
\hline $\mathrm{V}-01$ & Well & 393,576 & $4,077,242$ & 97 & 17 \\
\hline $\mathrm{V}-02$ & & 399,740 & $4,076,362$ & 58 & 19 \\
\hline $\mathrm{V}-03$ & & 396,064 & $4,075,339$ & 63 & 30 \\
\hline V-04 & & 399,436 & $4,074,674$ & 45 & 35 \\
\hline $\mathrm{V}-05$ & & 397,793 & $4,073,926$ & 35 & 33 \\
\hline V-06 & & 399,632 & $4,072,872$ & 31 & 33 \\
\hline V-07 & & 399,976 & $4,071,472$ & 25 & 36 \\
\hline V-08 & & 400,678 & $4,071,088$ & 22 & 20 \\
\hline V-09 & & 400,053 & $4,070,755$ & 21 & 40 \\
\hline $\mathrm{V}-10$ & & 400,736 & $4,070,038$ & 19 & 10 \\
\hline $\mathrm{V}-11$ & & 400,238 & $4,069,991$ & 20 & 25 \\
\hline $\mathrm{V}-12$ & & 400,587 & $4,069,307$ & 17 & 40 \\
\hline $\mathrm{V}-13$ & & 400,790 & $4,068,742$ & 16 & 40 \\
\hline V-14 & & 401,162 & $4,068,683$ & 14 & 18 \\
\hline $\mathrm{V}-15$ & & 400,879 & $4,068,084$ & 12 & 18 \\
\hline V-16 & & 400,878 & $4,067,764$ & 12 & 14 \\
\hline $\mathrm{V}-17$ & & 400,738 & $4,066,810$ & 9 & 11 \\
\hline V-18 & & 400,768 & $4,066,216$ & 6 & 10 \\
\hline V-19 & & 401,011 & $4,066,363$ & 5 & 9 \\
\hline V-20 & & 401,799 & $4,065,793$ & 3 & 4 \\
\hline $\mathrm{V}-21$ & & 400,433 & $4,065,637$ & 3 & 4 \\
\hline$V-22$ & & 400,843 & $4,065,518$ & 3 & 4 \\
\hline$V-23$ & & 400,772 & $4,065,306$ & 3 & 5 \\
\hline P1 & Piezometer & 400,220 & $4,065,655$ & 2.99 & 9 \\
\hline $\mathrm{P} 2$ & & 401,376 & $4,065,530$ & 2.42 & 50 \\
\hline P3 & & 401,020 & $4,065,870$ & 3.93 & 50 \\
\hline P4 & & 400,898 & $4,066,220$ & 5.73 & 40 \\
\hline P5 & & 401,080 & $4,065,725$ & 3.36 & 46 \\
\hline $\mathrm{S} 1$ & & 400,560 & $4,067,100$ & 6.20 & 45 \\
\hline $\mathrm{S} 2$ & & 400,738 & $4,066,810$ & 4.45 & 40 \\
\hline S3 & & 401,011 & $4,066,363$ & 5.62 & 45 \\
\hline S4 & & 401,100 & $4,066,365$ & 5.02 & 40 \\
\hline S5 & & 400,768 & $4,066,212$ & 4.05 & 40 \\
\hline S6 & & 401,740 & $4,066,075$ & 3.99 & 35 \\
\hline S7 & & 401,412 & $4,065,890$ & 3.56 & 35 \\
\hline S8 & & 400,433 & $4,065,637$ & 3.46 & 35 \\
\hline
\end{tabular}

surface water composition is documented for a dry year (1994/1995) and a wet year (1996/1997) (Table 2, Fig. 4). The ion composition is dominated by $\mathrm{Ca}, \mathrm{Mg}$ and $\mathrm{HCO}_{3}$, with elevated amounts of sodium and chloride in the deltaic sector (mainly in the western part) especially in the dry year, indicating seawater intrusion. In the upstream part of the aquifer, groundwater shows the lowest mineralisation values and is of the $\mathrm{Ca}-\mathrm{HCO}_{3}$ type, reflecting calcite dissolution. This concurs with carbonate rocks forming most 
Table 2 Ion analysis and ambient parameter of water samples

\begin{tabular}{|c|c|c|c|c|c|c|c|c|c|c|c|c|}
\hline ID & Sampling date & $T\left({ }^{\circ} \mathrm{C}\right)$ & $\mathrm{pH}$ & $\mathrm{EC}$ & $\mathrm{K}$ & $\mathrm{Na}$ & $\mathrm{Ca}$ & $\mathrm{Mg}$ & $\mathrm{Cl}$ & $\mathrm{SO}_{4}$ & $\mathrm{HCO}_{3}$ & $\mathrm{NO}_{3}$ \\
\hline River 01 & 11.12 .96 & 13.7 & 8.7 & 462.0 & 1.7 & 22.0 & 77.8 & 18.5 & 29.1 & 61.6 & 246.5 & 4.7 \\
\hline River 02 & 11.12 .96 & 16.2 & 7.4 & 1,041 & 4.8 & 66.8 & 135.5 & 29.7 & 89.3 & 146.9 & 361.2 & 68.0 \\
\hline River 02 & 23.01 .94 & 14.0 & 7.96 & 1,426 & 15.6 & 107.9 & 118.6 & 36.1 & 93.7 & 150.8 & 564.3 & 1.0 \\
\hline V-01 & 12.12 .96 & 18.6 & 7.4 & 780 & 1.7 & 42.1 & 110.6 & 38.9 & 55.3 & 146.1 & 306.3 & 31.8 \\
\hline V-01 & 17.01 .94 & 17.9 & 7.41 & 833 & 1.4 & 33.8 & 110.2 & 27.9 & 48.8 & 112.2 & 297.4 & 21.8 \\
\hline V-02 & 11.12 .96 & 19.2 & 7.5 & 573 & 2.5 & 32.7 & 74.1 & 30.6 & 34.7 & 78.6 & 281.9 & 14.1 \\
\hline V-02 & 17.01 .94 & 15.9 & 7.61 & 578 & 1.4 & 24.1 & 63.9 & 20.6 & 21.1 & 65.7 & 266.9 & 1 \\
\hline V-03 & 12.12 .96 & 19.0 & 7.4 & 825 & 1.5 & 47.4 & 98.6 & 47.2 & 61.0 & 149.9 & 308.8 & 45.0 \\
\hline V-03 & 17.01 .94 & 18.0 & 7.40 & 858 & 1.4 & 38.6 & 105.4 & 30.4 & 50.5 & 116.7 & 312.6 & 21.5 \\
\hline V-04 & 11.12 .96 & 18.9 & 7.23 & 1,260 & 3.4 & 106.9 & 137.1 & 57.6 & 159.5 & 173.4 & 438.1 & 56.6 \\
\hline V-04 & 19.01 .94 & 16.7 & 7.72 & 526 & 1.2 & 23.4 & 59.5 & 17.6 & 17.7 & 59.0 & 236.4 & 5.4 \\
\hline $\mathrm{V}-05$ & 12.12 .96 & 18.4 & 7.4 & 794 & 1.0 & 37.4 & 103.4 & 35.8 & 58.1 & 134.7 & 292.9 & 51.0 \\
\hline V-05 & 17.01 .94 & 19.0 & 7.29 & 878 & 0.6 & 33.3 & 109.4 & 34.6 & 44.3 & 93.2 & 335.5 & 41.5 \\
\hline V-06 & 11.12 .96 & 18.7 & 7.4 & 1056 & 3.3 & 44.8 & 142.3 & 49.4 & 80.8 & 147.5 & 342.9 & 146.7 \\
\hline V-06 & 19.01 .94 & 17.7 & 7.68 & 570 & 1.4 & 26.6 & 64.5 & 19.0 & 22.2 & 64.2 & 236.4 & 14.1 \\
\hline V-07 & 12.12 .96 & 18.7 & 7.2 & 1,108 & 1.7 & 53.4 & 145.5 & 45.7 & 82.2 & 186.9 & 327.1 & 153.0 \\
\hline V-07 & 19.01 .94 & 18.6 & 7.29 & 905 & 1.1 & 35.9 & 113.9 & 32.5 & 44.2 & 117.5 & 327.9 & 52.2 \\
\hline V-08 & 12.12 .96 & 18.0 & 7.8 & 843.0 & 2.1 & 40.7 & 110.2 & 36.2 & 61.7 & 128.9 & 297.8 & 89.7 \\
\hline V-08 & 19.01 .94 & 18.0 & 7.04 & 1,523 & 0.8 & 94.6 & 175.4 & 53.8 & 84.3 & 236.7 & 541.4 & 63.5 \\
\hline V-09 & 19.01 .94 & 18.4 & 7.66 & 1,084 & 2.5 & 39.6 & 140.0 & 40.6 & 53.3 & 144.0 & 366.0 & 95.1 \\
\hline $\mathrm{V}-10$ & 12.12 .96 & 17.5 & 7.02 & 1,623 & 6.4 & 113.6 & 197.6 & 78.1 & 116.3 & 325.0 & 425.9 & 221.5 \\
\hline V-10 & 31.01 .94 & 18.5 & 7.06 & 1,256 & 3.4 & 70.7 & 146.7 & 40.3 & 77.8 & 162.3 & 472.8 & 52.1 \\
\hline V-11 & 20.12 .96 & 19.9 & 7.3 & 1,666 & 2.8 & 60.8 & 261.3 & 70.0 & 136.1 & 312.7 & 397.8 & 238.7 \\
\hline V-11 & 31.01 .94 & 19.5 & 7.12 & 1,728 & 3.0 & 51.5 & 231.9 & 60.6 & 99.0 & 270.1 & 388.9 & 324.8 \\
\hline V-12 & 31.01 .94 & 19.2 & 7.20 & 1,045 & 1.4 & 51.3 & 115.7 & 33.0 & 54.6 & 133.2 & 396.5 & 51.4 \\
\hline $\mathrm{V}-13$ & 19.12 .96 & 20.5 & 7.5 & 881 & 3.3 & 46.8 & 136.7 & 34.5 & 66.6 & 134.7 & 312.4 & 81.4 \\
\hline V-13 & 31.01 .94 & 17.9 & 7.37 & 948 & 1.8 & 37.8 & 112.8 & 32.5 & 53.0 & 129.9 & 320.3 & 60.5 \\
\hline V-14 & 23.01 .94 & 16.2 & 7.22 & 1,572 & 4.0 & 85.2 & 162.1 & 62.8 & 97.9 & 274.4 & 526.1 & 94.2 \\
\hline $\mathrm{V}-15$ & 19.12 .96 & 20.3 & 7.6 & 960 & 2.7 & 57.4 & 145.5 & 36.2 & 71.6 & 153.5 & 372.2 & 83.9 \\
\hline V-15 & 23.01 .94 & 17.5 & 7.54 & 1,070 & 2.2 & 47.9 & 124.6 & 34.5 & 55.3 & 130.9 & 388.9 & 53.8 \\
\hline $\mathrm{V}-16$ & 19.12 .96 & 20.6 & 7.4 & 1,120 & 3.5 & 73.5 & 178.8 & 39.9 & 80.1 & 190.1 & 427.1 & 91.2 \\
\hline V-16 & 23.01 .94 & 19.1 & 7.33 & 980 & 2.3 & 45.3 & 114.5 & 31.5 & 49.8 & 121.6 & 366.0 & 45.2 \\
\hline $\mathrm{V}-17$ & 13.12 .96 & 19.0 & 7.7 & 1,226 & 2.5 & 93.5 & 151.5 & 52.5 & 115.6 & 192.3 & 405.2 & 102.2 \\
\hline $\mathrm{V}-17$ & 23.01 .94 & 16.7 & 7.51 & 892 & 2.9 & 49.9 & 99.8 & 25.5 & 54.7 & 96.2 & 388.9 & 3.8 \\
\hline $\mathrm{V}-18$ & 13.12 .96 & 18.7 & 7.0 & 1421 & 3.1 & 100.2 & 185.2 & 48.2 & 134.0 & 239.6 & 421.0 & 158.8 \\
\hline V-18 & 23.01 .94 & 19.1 & 6.95 & 6730 & 8.8 & 584.2 & 513.6 & 167.6 & 1653.0 & 443.0 & 396.5 & 148.4 \\
\hline V-19 & 12.12 .96 & 16.4 & 7.3 & 1,098 & 3.7 & 80.2 & 141.9 & 36.0 & 87.2 & 187.0 & 366.1 & 87.9 \\
\hline V-19 & 23.01 .94 & 19.9 & 6.99 & 6,990 & 19.0 & 961.0 & 449.0 & 168.0 & 1939.0 & 477.8 & 457.5 & 99.8 \\
\hline $\mathrm{V}-20$ & 19.12 .96 & 20.0 & 7.4 & 1,910 & 7.6 & 193.7 & 244.1 & 66.6 & 234.0 & 365.9 & 533.3 & 156.8 \\
\hline $\mathrm{V}-20$ & 23.01 .94 & 17.9 & 7.36 & 1,977 & 4.5 & 120.5 & 228.5 & 53.4 & 227.3 & 338.1 & 366.0 & 170.3 \\
\hline V-21 & 19.12 .96 & 20.2 & 7.3 & 1,898 & 6.4 & 187.0 & 219.2 & 64.0 & 308.4 & 276.1 & 433.2 & 142.5 \\
\hline $\mathrm{V}-21$ & 23.01 .94 & 18.1 & 7.14 & 2,830 & 11.9 & 180.1 & 326.1 & 95.6 & 414.4 & 410.7 & 434.6 & 303.0 \\
\hline V-22 & 23.01 .94 & 14.4 & 7.29 & 8,330 & 26.0 & 2981.0 & 820.0 & 432.0 & 5910.0 & 949.0 & 366.0 & 171.0 \\
\hline
\end{tabular}

Ion concentrations are given in $\mathrm{mg} / \mathrm{L}$. EC (electric conductivity) is given in $\mu \mathrm{s} / \mathrm{cm}$

of the watershed boundaries, drained by springs that are responsible for the Velez river baseflow. Grey symbols of the central aquifer part indicate higher proportions of
$\mathrm{HCO}_{3}$ in the dry year, whereas relative amounts of sulphate increase in wet years, indicating remobilisation of inorganic fertilisers owing to rising groundwater tables. 


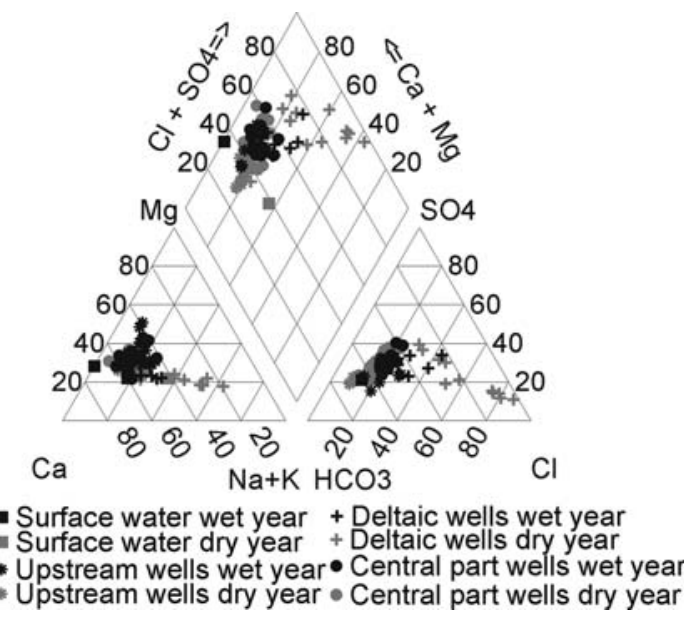

Fig. 4 Piper diagram of analysed ground- and surface water sampled for dry (1994) and wet (1996) hydrological conditions

Significant occurrence of gypsum in this watershed has not been reported and therefore can be excluded as a possible source of sulphate. In the deltaic sector, the groundwater varies widely from the $\mathrm{Ca} \mathrm{SO}_{4}-\mathrm{HCO}_{3}$ type in the wet year to $\mathrm{Ca}-\mathrm{Cl}$ and $\mathrm{Na}-\mathrm{Cl}$ types in the dry year owing to seawater intrusion.

The Schoeller diagram (Fig. 5) shows a general increase of mineralisation along the flow path. The highest intensity of agricultural activity in the central part is reflected by maximum nitrate concentrations in this area. In general, wet conditions result in elevated nitrate and sulphate

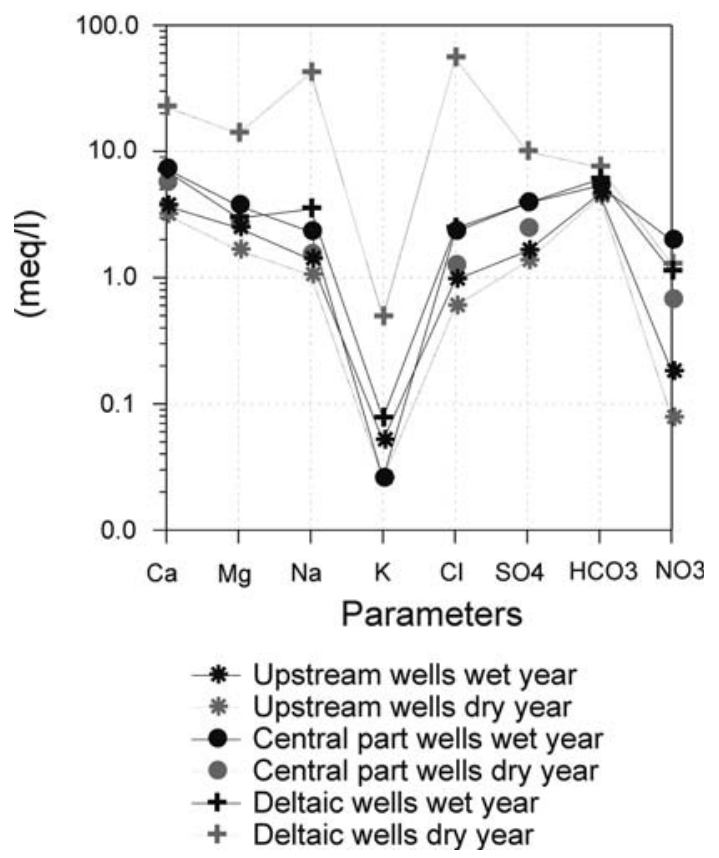

Fig. 5 Schoeller diagram showing hydrogeochemical evolution of groundwater along the flowpath during dry (1994) and wet (1996) conditions concentrations due to the remobilisation of inorganic fertilisers in the unsaturated zone which holds for the entire aquifer. Also $\mathrm{Ca}$, $\mathrm{Na}$ and $\mathrm{K}$ show higher concentrations during the wet period.

Again, seawater intrusion during the dry season results in elevated concentrations of sodium and chloride in the deltaic sector. Sodium/chloride ratios below 1 in the dry year indicate $\mathrm{CaCl}_{2}$ water, pointing to desorption of calcium and sorption of sodium during seawater intrusion. Elevated potassium concentrations in the deltaic sector are also related to seawater intrusion. Potassium values in the upstream area are higher than in the central part, excluding agricultural activity as an input source and indicating the influence of waste water, which concurs with elevated sodium chloride ratios.

The hydrochemical patterns of groundwater and Velez River are similar with slightly higher concentrations in the groundwater as shown for the wet year 1996 in Fig. 6. This holds also for the other sectors of the aquifer and points to gaining river conditions discharging the aquifer.

Surface water composition in the central part (Fig. 7) shows considerable variations in time. As discussed above, here too the composition of the Velez River is similar to the groundwater composition. Wet conditions lead to elevated nitrate contents caused by lixiviation of the fertilisers. Decreasing potassium from 1994 to 2007 cannot be explained only by decreasing rainfall and higher relative amounts of wastewater because rainfall in 2007 was higher than in 1996. This may be related to the purification plant which started to operate in 2006.

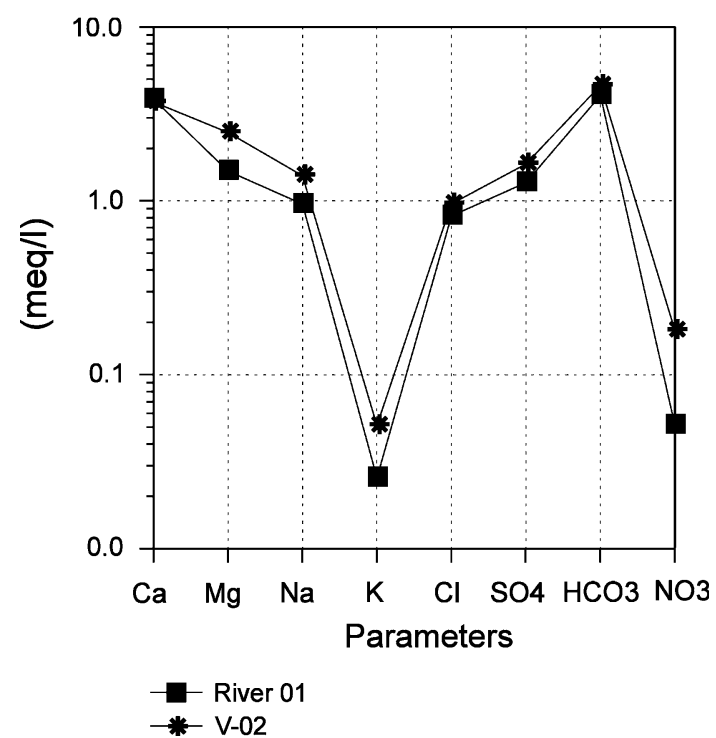

Fig. 6 Schoeller diagram showing hydrogeochemistry of Velez River and groundwater for wet conditions (1996) 


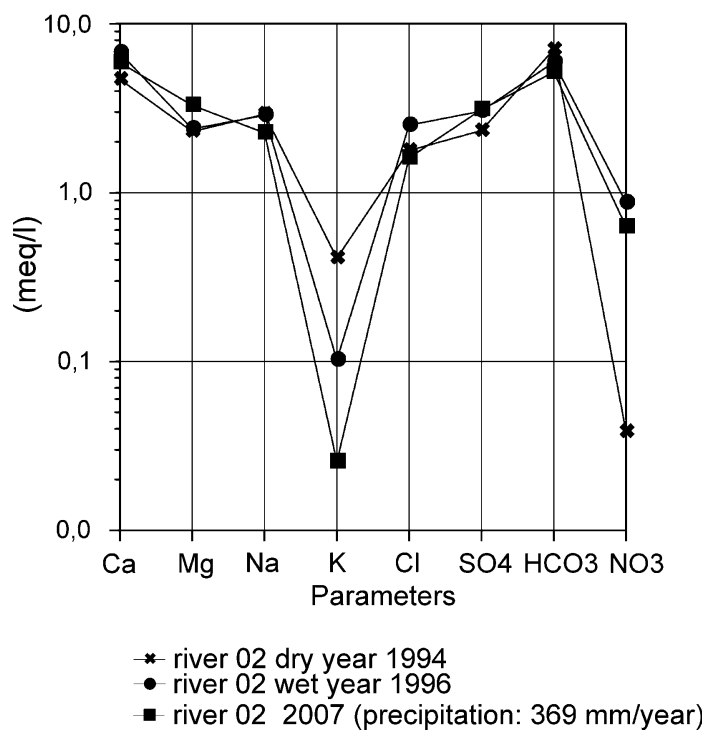

Fig. 7 Schoeller diagram showing the hydrogeochemistry of Velez River between 1994 and 2007 including dry (1994), wet (1996) and slightly dry hydrologic conditions

Principal component analysis (PCA)

Principal component analysis is applied to simplify the rather complex set of data and to differentiate between different chemical environments at the site. PCA (Davis 2002) is a method for reducing the dimensionality of multivariate data sets such as the nine water quality variables that are presented here for each of the monitoring well locations during wet and dry conditions. Since many of the chemical variables are positively or negatively correlated, some of the variables essentially contain the same information. PCA finds a new orthogonal coordinate system of uncorrelated variables to represent the original chemical data.

The sample entries contain nine chemical parameters for each of the sample locations: $\mathrm{EC}, \mathrm{Ca}, \mathrm{Mg}, \mathrm{Na}, \mathrm{K}, \mathrm{Cl}, \mathrm{SO}_{4}$, $\mathrm{HCO}_{3}$ and $\mathrm{NO}_{3}$. PCA was applied to the samples listed in Table 2 separately for 1994 (dry year) and 1996 (wet year). The first two principal components in both analysis account for over $89 \%$ of the variability in the data set, and will therefore be used in the following analysis. As shown in Fig. 8 all variables have positive loadings on principal component 1 (PC1). Consequently, samples with elevated $\mathrm{EC}, \mathrm{Ca}, \mathrm{Mg}, \mathrm{Na}, \mathrm{K}, \mathrm{Cl}, \mathrm{SO}_{4}, \mathrm{HCO}_{3}$ and $\mathrm{NO}_{3}$ will tend to have high values of $\mathrm{PC} 1$. The correlation matrix calculated by PCA analysis for all samples listed in Table 2 are presented in Table 3 and indicate high correlations between all parameters except for $\mathrm{HCO}_{3}$ and $\mathrm{NO}_{3}$. The general variability of ion concentrations and EC is interpreted as mineralisation due to water rock interaction along the flow path. Comparison of variable loadings on PC1 in 1994 and 1996 yields higher values for 1994 reflecting a larger variability caused by seawater intrusion and an increased

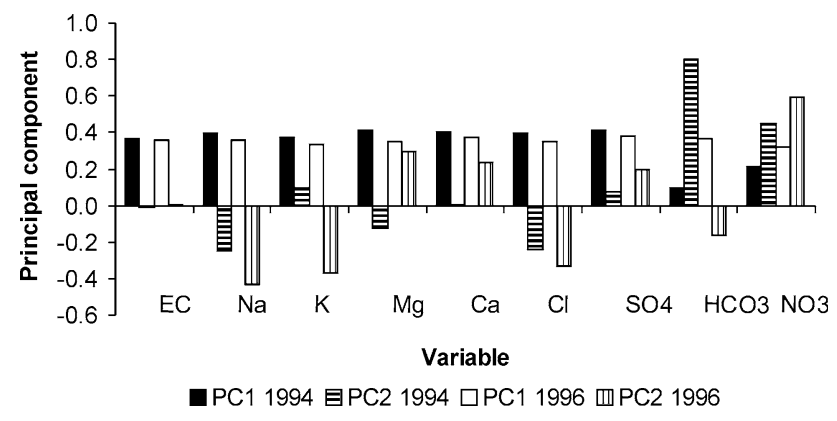

Fig. 8 Loadings of variables on first two principal components of hydrochemical data. PC1 and PC2 refer to principal component one and two, respectively

Table 3 Correlation matrix calculated by PCA of all samples listed in Table 2

\begin{tabular}{llllllllll}
\hline & $\mathrm{EC}$ & $\mathrm{Na}$ & $\mathrm{K}$ & $\mathrm{Mg}$ & $\mathrm{Ca}$ & $\mathrm{Cl}$ & $\mathrm{SO}_{4}$ & $\mathrm{HCO}_{3}$ & $\mathrm{NO}_{3}$ \\
\hline $\mathrm{EC}$ & 1.00 & 0.85 & 0.85 & 0.91 & 0.96 & 0.88 & 0.89 & 0.29 & 0.39 \\
$\mathrm{Na}$ & 0.85 & 1.00 & 0.82 & 0.97 & 0.89 & 1.00 & 0.87 & 0.11 & 0.22 \\
$\mathrm{~K}$ & 0.85 & 0.82 & 1.00 & 0.84 & 0.84 & 0.82 & 0.84 & 0.40 & 0.32 \\
$\mathrm{Mg}$ & 0.91 & 0.97 & 0.84 & 1.00 & 0.96 & 0.98 & 0.94 & 0.20 & 0.38 \\
$\mathrm{Ca}$ & 0.96 & 0.89 & 0.84 & 0.96 & 1.00 & 0.91 & 0.97 & 0.30 & 0.53 \\
$\mathrm{Cl}$ & 0.88 & 1.00 & 0.82 & 0.98 & 0.91 & 1.00 & 0.87 & 0.09 & 0.24 \\
$\mathrm{SO}_{4}$ & 0.89 & 0.87 & 0.84 & 0.94 & 0.97 & 0.87 & 1.00 & 0.39 & 0.60 \\
$\mathrm{HCO}_{3}$ & 0.29 & 0.11 & 0.40 & 0.20 & 0.30 & 0.09 & 0.39 & 1.00 & 0.33 \\
$\mathrm{NO}_{3}$ & 0.39 & 0.22 & 0.32 & 0.38 & 0.53 & 0.24 & 0.60 & 0.33 & 1.00 \\
\hline
\end{tabular}

$E C$ electric conductivity

maximum mineralization during 1994. Variations of $\mathrm{pH}$ are small and are therefore not further regarded here. The only distinct $\mathrm{pH}$ value of 8.7 analysed at station River 01 (Table 2) reflects equilibrium of surface water with calcite and atmospheric $\mathrm{CO}_{2}$.

PC2 shows positive variable loadings for $\mathrm{HCO}_{3}$ and nitrate. According to the correlation matrix calculated with XLSTAT for all samples of 1994 and $1996 \mathrm{HCO}_{3}$ and nitrate do not show any correlations (Table 3 ). In contrast, during wet conditions, nitrate correlates with $\mathrm{EC}, \mathrm{Mg}, \mathrm{Ca}$ and $\mathrm{SO}_{4}$ as shown in Table 4 pointing to the local use of inorganic fertilizers in 1996 . The fertilisers probably have been remobilised by ascending groundwater tables into the unsaturated zone. During dry conditions no correlation exists between nitrate and the other parameters.

Alkalinity is not correlated with nitrate and its variability may be related to local variations in $\mathrm{CO}_{2}$ pressure of soil air and subsequent calcite dissolution originated by biodegradation.

\section{Salinisation}

In the coastal part of the aquifer, the presence of the impervious silt and clay levels allows two superposed units 
Table 4 Correlation matrix of all samples listed in Table 2 calculated by PCA separately for dry (1994) and wet (1996) conditions

\begin{tabular}{|c|c|c|c|c|c|c|c|c|c|c|c|c|c|c|c|c|c|c|}
\hline & \multicolumn{2}{|l|}{ EC } & \multicolumn{2}{|l|}{$\mathrm{Na}$} & \multicolumn{2}{|l|}{ K } & \multicolumn{2}{|l|}{$\mathrm{Mg}$} & \multicolumn{2}{|l|}{$\mathrm{Ca}$} & \multicolumn{2}{|l|}{$\mathrm{Cl}$} & \multicolumn{2}{|l|}{$\mathrm{SO}_{4}$} & \multicolumn{2}{|c|}{$\mathrm{HCO}_{3}$} & \multicolumn{2}{|l|}{$\mathrm{NO}_{3}$} \\
\hline & Wet & Dry & Wet & Dry & Wet & Dry & Wet & Dry & Wet & Dry & Wet & Dry & Wet & Dry & Wet & Dry & Wet & Dry \\
\hline EC & 1.00 & 1.00 & 0.88 & 0.85 & 0.78 & 0.85 & 0.88 & 0.91 & 0.94 & 0.96 & 0.89 & 0.88 & 0.95 & 0.91 & 0.89 & 0.24 & 0.81 & 0.44 \\
\hline $\mathrm{Na}$ & 0.88 & 0.85 & 1.00 & 1.00 & 0.85 & 0.83 & 0.69 & 0.98 & 0.73 & 0.91 & 0.94 & 1.00 & 0.80 & 0.90 & 0.88 & 0.07 & 0.48 & 0.28 \\
\hline $\mathrm{K}$ & 0.78 & 0.85 & 0.85 & 0.83 & 1.00 & 1.00 & 0.59 & 0.84 & 0.68 & 0.84 & 0.75 & 0.83 & 0.73 & 0.85 & 0.77 & 0.36 & 0.51 & 0.36 \\
\hline $\mathrm{Mg}$ & 0.88 & 0.91 & 0.69 & 0.98 & 0.59 & 0.84 & 1.00 & 1.00 & 0.80 & 0.97 & 0.71 & 0.99 & 0.89 & 0.96 & 0.74 & 0.14 & 0.81 & 0.42 \\
\hline $\mathrm{Ca}$ & 0.94 & 0.96 & 0.73 & 0.91 & 0.68 & 0.84 & 0.80 & 0.97 & 1.00 & 1.00 & 0.76 & 0.93 & 0.94 & 0.98 & 0.83 & 0.21 & 0.86 & 0.55 \\
\hline $\mathrm{Cl}$ & 0.89 & 0.88 & 0.94 & 1.00 & 0.75 & 0.83 & 0.71 & 0.99 & 0.76 & 0.93 & 1.00 & 1.00 & 0.76 & 0.92 & 0.79 & 0.05 & 0.52 & 0.31 \\
\hline $\mathrm{SO}_{4}$ & 0.95 & 0.91 & 0.80 & 0.90 & 0.73 & 0.85 & 0.89 & 0.96 & 0.94 & 0.98 & 0.76 & 0.92 & 1.00 & 1.00 & 0.85 & 0.28 & 0.84 & 0.59 \\
\hline $\mathrm{HCO}_{3}$ & 0.89 & 0.24 & 0.88 & 0.07 & 0.77 & 0.36 & 0.74 & 0.14 & 0.83 & 0.21 & 0.79 & 0.05 & 0.85 & 0.28 & 1.00 & 1.00 & 0.61 & 0.21 \\
\hline $\mathrm{NO}_{3}$ & 0.81 & 0.44 & 0.48 & 0.28 & 0.51 & 0.36 & 0.81 & 0.42 & 0.86 & 0.55 & 0.52 & 0.31 & 0.84 & 0.59 & 0.61 & 0.21 & 1.00 & 1.0 \\
\hline
\end{tabular}

EC electric conductivity

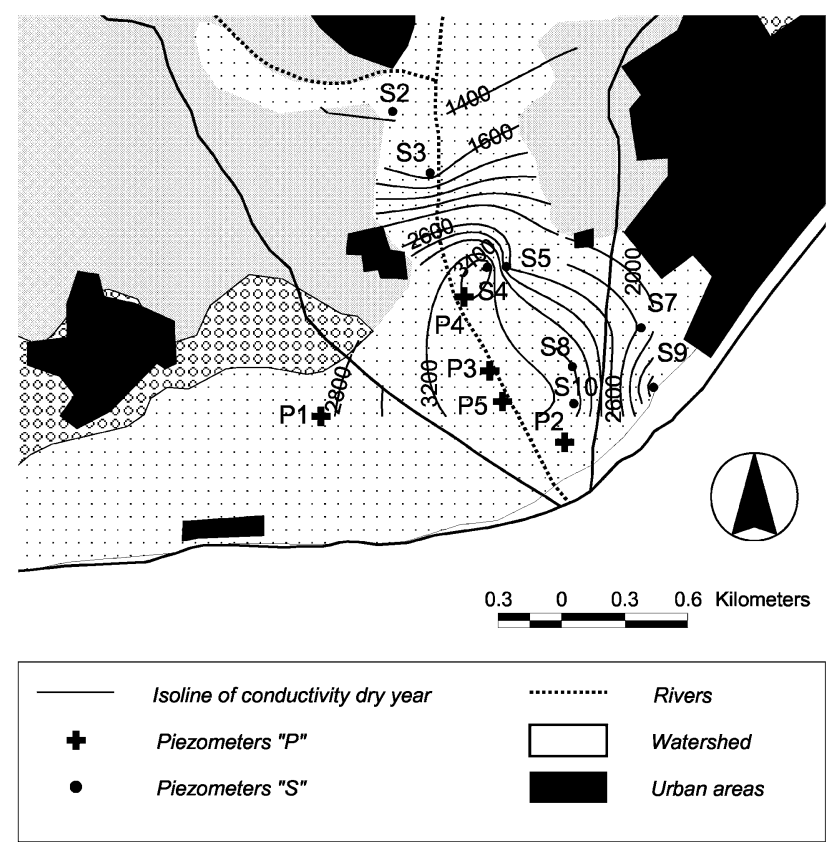

Fig. 9 Map of isoconductivity lines for dry hydrologic conditions (1994) based on measurements at piezometers $S$. Conductivities are given in $\mu \mathrm{s} / \mathrm{cm}$

to be distinguished: an upper unconfined and a lower confined aquifer. The thickness is around $15 \mathrm{~m}$ for the upper and between 20 and $30 \mathrm{~m}$ for the lower confined aquifer (CHSE 1997).

Owing to the scarcity of observation points in the confined aquifer the spatial variation of conductivities could only be investigated for the upper aquifer of the deltaic sector. Figure 9 shows an increasing salinisation towards the coast and also towards the Velez River. This clearly indicates seawater intrusion, but also points to preferential pathways of seawater intrusion probably related to higher hydraulic conductivities of the sediments. It demonstrates that seawater intrusion depends strongly on local

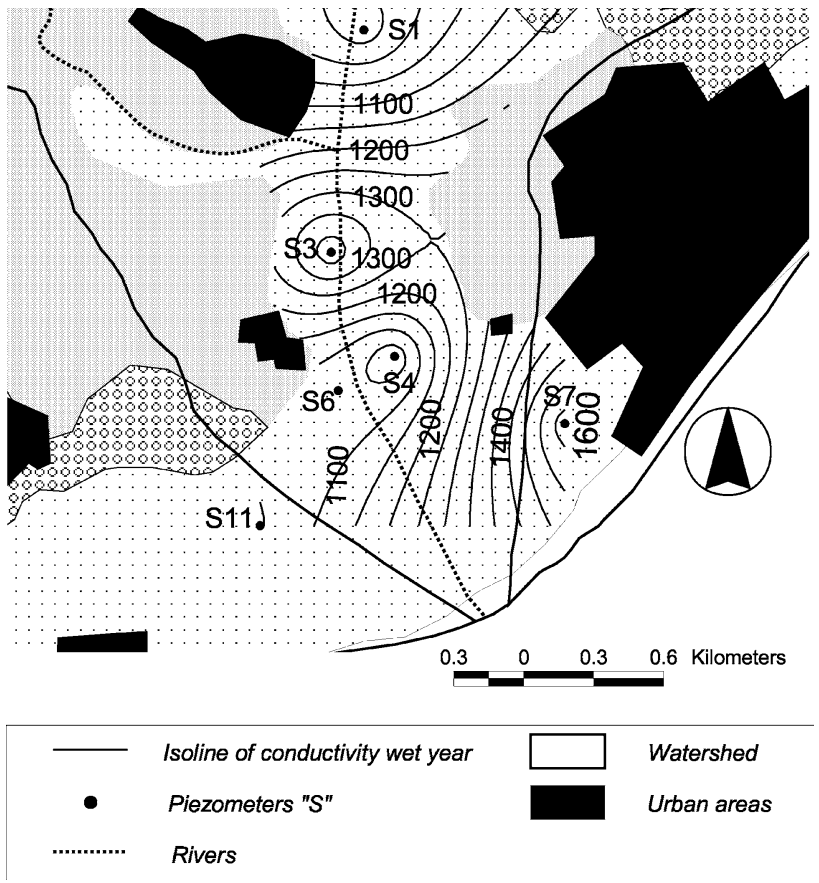

Fig. 10 Map of isoconductivity lines for wet hydrologic conditions (1996) based on measurements at piezometers $S$. Conductivities are given in $\mu \mathrm{s} / \mathrm{cm}$

geological conditions and may constitute a three-dimensional problem which cannot always be handled by twodimensional vertical modelling approaches which are still a scientific standard of presenting density driven flow processes.

During the wet year conductivities are increasing towards the zones of intensive agriculture and reveal the influence of anthropogenic input of nitrates (Fig. 10), which concurs with hydrochemical data of the groundwater. This is supported also by the correlation matrix presented separately for wet and dry conditions in Table 4 as discussed above. Saline intrusion is not visible in 1996. 


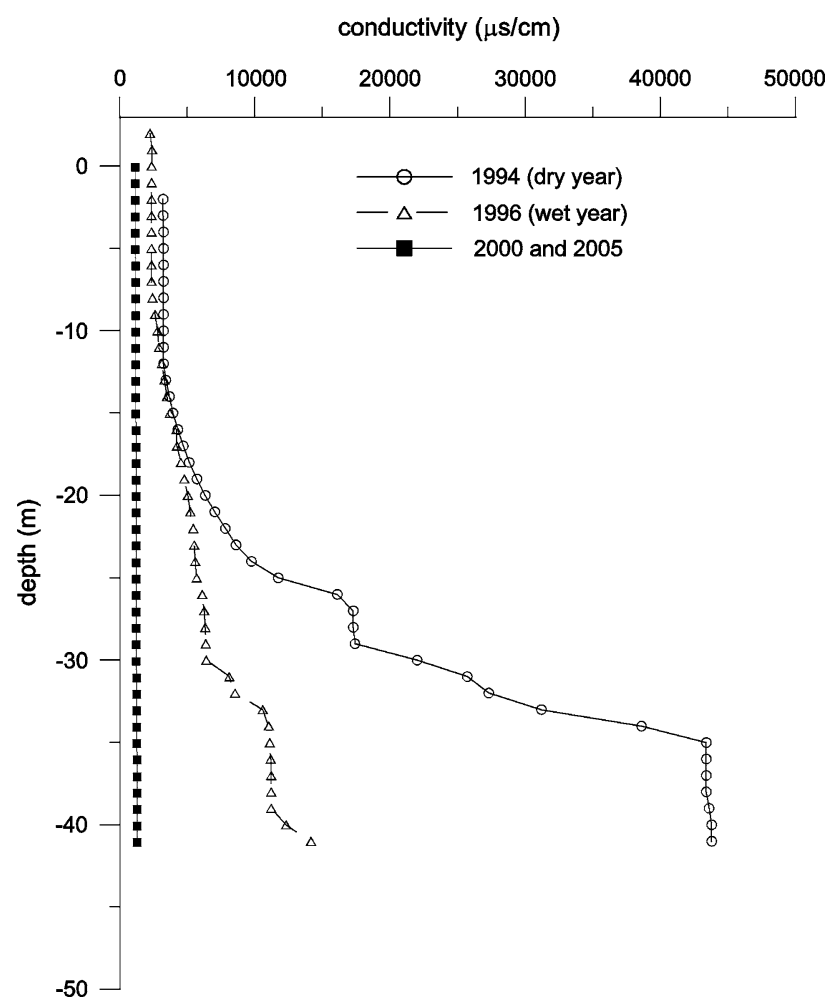

Fig. 11 Depth profiles of electric conductivities measured at P4 (see Fig. 8)

To obtain information about the saltwater-freshwater interface, conductivity $\operatorname{logs}$ in the deltaic sector were carried out for the confined aquifer at P3 (Fig. 11). In principle, mineralisation increases with depth showing a maximum mineralisation during the dry year around $-30 \mathrm{~m}$ below surface, which corresponds to the depth of the seawater-freshwater interface. Also in the wet year, seawater intrusion is visible in the conductivity profile. According to Ghyben-Herzberg (Herzberg 1901) the depth of interface is calculated by:

$H_{\mathrm{s}}=\left(\rho_{\mathrm{f}} /\left(\rho_{\mathrm{s}}-\rho_{\mathrm{f}}\right)\right) / H_{\mathrm{f}}$

where $H_{\mathrm{s}}$ is the depth of the interface, $H_{\mathrm{f}}$ is the elevation of the water table above sea level, $\rho_{\mathrm{f}}$ is the density of the freshwater, and $\rho_{\mathrm{s}}$ is the density of salt water.

$H_{\mathrm{f}}$ of 0.93 masl measured at P4 in the dry year of 1994 and $\rho_{\mathrm{s}}$ of $1.03 \mathrm{~kg} / \mathrm{l}$, representative for the Mediterranean, lead to an interface depth of $30.95 \mathrm{~m}$ which agrees with our observations.

Figure 11 also shows a trend of saline extrusion from 1996 to 2000 in spite of less rainfall in 2005 in comparison with 1996. This is related to the La Viñuela Reservoir, which was replenished until 2005, discharging high amounts of water into the river and then increasing recharge to the aquifer. This was accompanied by decreasing pumping activity at the end of the nineties.

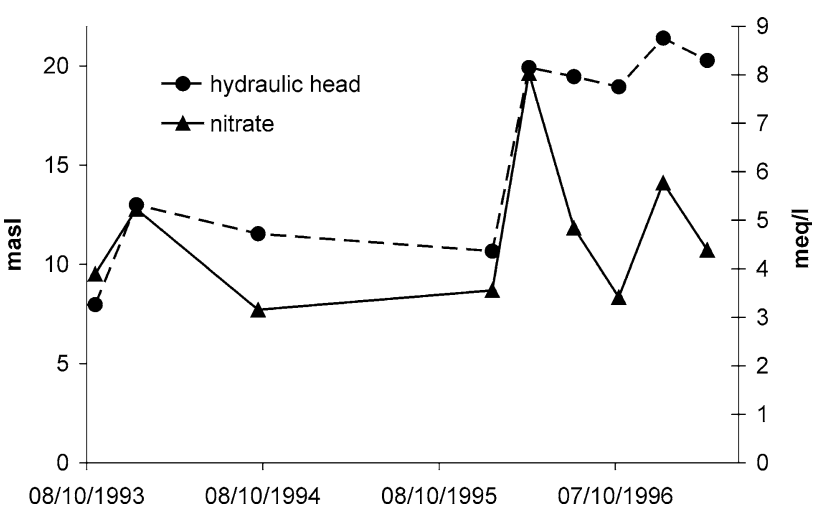

Fig. 12 Time series of nitrate concentrations and piezometric head measured at V-11 between 1993 and 1997 (for location of V-11 refer to Fig. 1)

Nitrates

To verify the hypothesis discussed above that nitrate is remobilised by ascending water tables the impact of hydrologic conditions on the nitrate concentration of the groundwater was studied at piezometer V-11. This piezometer provides long time series of nitrate data from 1993 to 1997 (Fig. 12) and is located in the central part of the aquifer (Fig. 1). A strong correlation of rising groundwater level with increasing nitrate concentrations can be observed, which is related to the uptake of nitrates from the unsaturated zone. It is interesting to note that elevated nitrate concentrations decrease immediately after having reached their peak, although groundwater maintains its high level. This suggests a fast replacement of groundwater by less contaminated water recharged in the upper part of the aquifer.

\section{Stable isotopes}

To identify the origin of nitrates which may be waste water, organic or inorganic fertilisers, stable isotopic analysis of $\delta^{15} \mathrm{~N}$ was carried out in 2007 at Vel-07 giving a value of $9.15 \%$ (Fig. 1). No presence of nitrites or ammonium was detected here, and also the TOC analysis gives low values, affirming that original isotopic signatures had not been modified by denitrification. Data from a study at the University of Barcelona regarding all the inorganic fertilisers used in Spain (Vitória et al. 2004) show that these fertilisers have a $\delta^{15} \mathrm{~N}$ value of around $0 \%$, pointing to a considerable nitrate input due to organic fertilisers which show a $\delta^{15} \mathrm{~N}$ of around $6 \%$.

Stable $\mathrm{D} /{ }^{18} \mathrm{O}$ isotopes may provide important information about recharge sources. They were sampled in November 2007 at 11 different wells and the La Viñuela reservoir (Fig. 13, Table 5). 


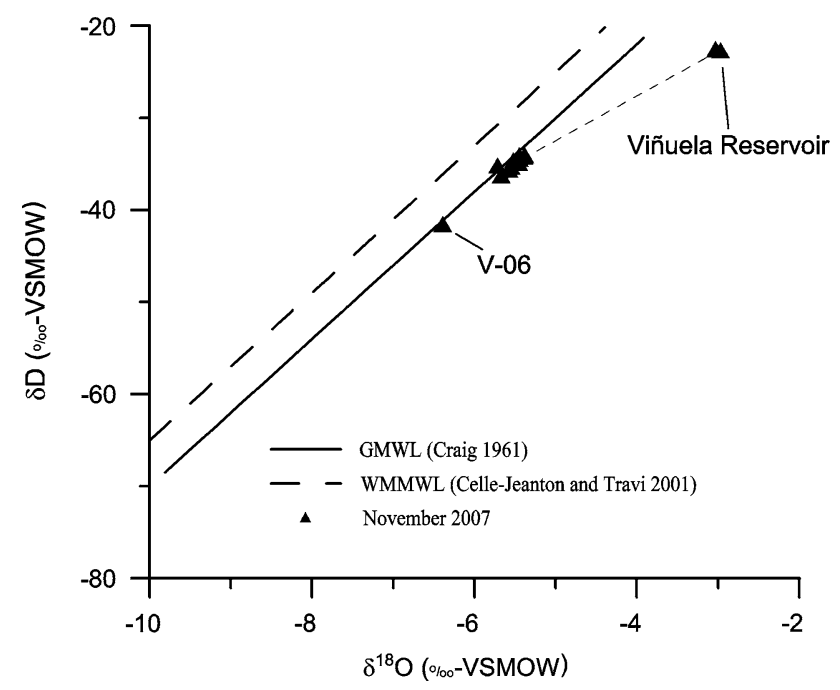

Fig. $13 \mathrm{D} /{ }^{18} \mathrm{O}$ composition of groundwater and Viñuela reservoir sampled in 2007

Table 5 D $/ 18^{\circ}$ composition of ground and surface water

\begin{tabular}{llll}
\hline ID & $\begin{array}{l}\delta^{18} \mathrm{O}(\%) \text { vs. } \\
\text { SMOW }\end{array}$ & $\begin{array}{l}\delta \mathrm{D}(\%) \text { vs. } \\
\text { SMOW }\end{array}$ & $d$ excess $(\%)$ \\
\hline Vinuela & -3.03 & -22.5 & 1.7 \\
TM & -2.97 & -22.7 & 1.1 \\
V-05 & -5.72 & -35.1 & 10.6 \\
V-06 & -6.39 & -41.5 & 9.6 \\
V-07 & -5.45 & -34.4 & 9.2 \\
V-11 & -5.38 & -34.0 & 9.0 \\
V-12 & -5.67 & -36.2 & 9.2 \\
V-13 & -5.57 & -35.6 & 9.0 \\
V-15 & -5.55 & -35.3 & 9.2 \\
P2 & -5.46 & -34.9 & 8.8 \\
P3 & -5.45 & -34.0 & 9.6 \\
P4 & -5.53 & -34.6 & 9.6 \\
P5 & -5.39 & -34.2 & 9.0 \\
\hline
\end{tabular}

The isotopic signatures of the groundwater are plotted along the GMWL, indicating an Atlantic source of the precipitation. This is in contrast to other studies in Andalusia where an influence of the western Mediterranean has also been reported (Cruz San Julian et al. 1992; Andreo et al. 2004; Kohfahl et al. 2008). V-06 shows a clearly lighter isotopic signature, indicating higher recharge altitudes than the other points. This well is located close to the eastern aquifer boundary (Fig. 1) and may receive important discharge from the adjacent, more permeable conglomerates recharged by the nearest mountains, Sierra Tejeda-Almijara.

The La Viñuela reservoir plots along an evaporation line with an approximate slope of 6.3. The evaporation signature is no longer visible in the groundwater, leading to the conclusion that in the present conditions the aquifer is recharged only to a minor degree by water coming from the reservoir.

\section{Conclusions}

In this study, hydrochemical and hydraulic data of the years 1994 and 1996 were analysed in order to investigate the impact of hydrological conditions on seawater intrusion and nitrate concentration in the Velez-Malaga aquifer. Additionally, stable isotope data of $\mathrm{D},{ }^{18} \mathrm{O}$ and ${ }^{15} \mathrm{~N}$ sampled in 2007 are presented and evaluated to delineate recharge- and nitrate sources.

The following conclusions can be drawn from this study

- A general trend of rising mineralisation along the flowpath was observed. This is supported by PCA analysis yielding correlations between all parameters except for $\mathrm{pH}, \mathrm{HCO}_{3}$ and nitrate.

- Seawater intrusion occurs during dry conditions in 1994 enhanced by intensive groundwater extraction for irrigation purpose. Posterior watershed management with the Viñuelas Reservoir and less dry hydrological conditions have prevented seawater intrusion until 2005.

- Irregular patterns of EC in the deltaic sector in 1994 point to preferential pathways of seawater intrusion related to higher hydraulic conductivities of the sediments.

- Patterns of EC in the deltaic sector and the EC-nitrate correlation in 1996 point to control of mineralisation by fertilizers in agricultural areas during wet conditions due to ascending groundwater levels.

- The correlation between nitrate, $\mathrm{Mg}, \mathrm{Ca}$, sulphate and EC during wet conditions in 1996 indicates uptake of mainly inorganic fertilizers due to ascending water levels. This is supported by the correlation between nitrate concentration and groundwater level.

- $\mathrm{D}$ and ${ }^{18} \mathrm{O}$ analyses of samples from 2007 indicate an Atlantic source of the precipitation. One sample shows a considerably lighter isotopic signature pointing to higher recharge altitudes than the other points. The evaporitic signature of the Viñuelas reservoir is no longer visible in the groundwater, leading to the conclusion that in the present conditions the aquifer is recharged only to a minor degree by water coming from the reservoir.

- ${ }^{15} \mathrm{~N}$ values of samples from 2007 point to organic fertilizers as the main source of nitrates.

Acknowledgments This work has been funded by the Geological Survey of Spain, IGME, and the Water Mediterranean Basin Board (AquaMed: Ministry of Environment, Government of Spain). It 
benefits from studies carried out in the framework of the SWIMED Project (ICA3-CT-2002-10004, INCO Program, European Commission). The authors acknowledge the collaboration of the Andalusian Mediterranean Basin Authority (Autonomous Government of Andalusia, Spain) for providing hydrological data as well as the access to monitoring points.

\section{References}

Andreo B, Liñán C, Jiménez-Cisneros C, Caballero F, Mudry J (2004) Influence of rainfall quantity on the isotopic composition (18O and $2 \mathrm{H}$ ) of water in mountainous areas. Application for groundwater research in the Yunquera-Nieves karst aquifers (S Spain). Appl Geochem 19:561-574

Bear J, Cheng A, Sorek S, Ouazar D, Herrera I (eds) (1999) Seawater intrusion in coastal aquifers-concepts, methods and practices. Kluwer Academic Publishers, Dordrecht, $625 \mathrm{p}$

Benavente J, El Mabrouki K, Himi M, García-Aróstegui JL, Calabrés C, y Casas A (2005) Uso de técnicas geofísicas para caracterizar la extrusión de agua salina en un acuífero costero mediterráneo bicapa (Río Vélez, provincia de Málaga). Geogaceta 37:127-130

Calvache ML, Pulido-Bosch A (1997) Effects of geology and human activity on the dynamics of salt-water intrusion in three coastal aquifers in southern Spain. Environ Geol 30(3-4):215-223

Celle-Jeanton H, Travy Y, Blavoux B (2001) Isotopic typology of the precipitation in the Western Mediterranean region at three different time scales. Geophys Res Lett 28:1215-1218

CHSE (1987) Estudio hidrológico de los ríos Vélez y Benamargosa., edited, Dirección General de Obras Hidráulicas. Confederación Hidrografica del Sur de España

CHSE (1997) Asistencia técnica para el seguimiento, conservación y explotación del estudio hidrológico de los ríos Vélez y Benamargosa (Málaga) y control de su calidad. Dirección General de Obras Hidráulicas. Confederación Hidrográfica del Sur de España

Cruz San Julian JJ, Araguas L, Rozanski K, Benavente J, Cardenal J, Hidalgo MC, García López S, Martinez Garrido JC, Moral F, Olias M (1992) Sources of precipitation over South-Eastern Spain and groundwater recharge. An isotopic study. Tellus 44B:226-236

Davis JC (2002) Statistics and data analysis in geology. Wiley, New York, p 638

Dimopoulos M, Chalkidaki M, Dassenakis M, Scoullos M (2003) Quality of groundwater in western Thessaly the problem of nitrate pollution. Global Nest 5(3):185-191

García-Aróstegui JL (1998) Estudio hidrogeológico y modelización del acuífero de los ríos Vélez y Benamargosa (Málaga). Tesis Doctoral. Universidad de Granada. Memoria inédita, 377 pp

García-Aróstegui JL, Hidalgo MC, Benavente J (2005) Groundwater quality monitoring in a coastal Mediterranean aquifer affected by agricultural contamination and seawater intrusion-extrusion processes (Vélez river, Andalusia, Spain). In: Benavente J, Larabi A, El-Mabrouki K (eds) Monitoring, modelling and management of coastal aquifers. Instituto Geológico y Minero de España, Granada, pp 301-313

García-Aróstegui JL, Hidalgo MC, y Cruz San Julián J (1996) Estimación de los aportes anuales de nitrógeno al aluvial del río Vélez (Málaga). IV SIAGA II:275-283 (IGME)

Herzberg B (1901) Die Wasserversorgung einiger Nordseebäder. J Gasbeleuchtung Wasserversorgung 44:815-819, 842-844

Kohfahl C, Sprenger C, Benavente Herrera J, Meyer H, Fernandez Chacon P, Pekdeger A (2008) Recharge sources and hydrogeochemical evolution of groundwater in semiarid and karstic environments: a field study in the Granada Basin (Southern Spain). Appl Geochem 23(4):846-862

Martin-Vivaldi ME (1991) Estudio hidrografico de la Cuenca Sur de España. Universidad de Granada. Colecc Monogr Tierras del Sur, $285 \mathrm{p}$

Paniconi GC, Khlaifi I, Giuditta L, Giacomelli A, Tarhouni J (2001) Modeling and analysis of seawater intrusion in the coastal aquifer of eastern Cap-Bon, Tunisia. Transp Porous Media 43:328

Rejani R, Jha Madan K, Panda SN, Mull R (2008) Simulation modeling for efficient groundwater management in balasore coastal basin, India. Water Resour Manage, vol 22, No 1, Netherlands

RUSCH (1993) Hydrochemische und bakteriologische Untersuchungen der Grundwasserkontamination im unteren río Vélez Tal (Málaga/Südspanien). Diplomarbeit, Freie Universität Berlin

Senciales Gonzales JM (1995) La cuenca del río Velez. Estudio Hydrográfico. Tésis doctoral. Universidad de Malaga, Malaga, p 1327

Vadillo I, Benavente J, El-Mabrouki K, Carrasco F, López V, y García-Aróstegui JL (2007) Distribution of nitrogen species and evidence of denitrification in the Velez river aquifer (south of Spain). Water Pollution in natural Porous media at different scales. Assessment of fate, impact and indicators. WAPO2: In: Candela L, Vadillo I, Aagard P, Bedbur E, Trevisan M, Vanclooster M, Viotti P, López-Geta JA (eds) Publicaciones del Instituto Geológico y Minero de España. Serie Hidrogeología y Aguas Subterráneas $\mathrm{N}^{\circ}$ 22, Madrid, pp 549-556

Vitória L, Otero N, Soler A, Canals A (2004) Fertilizers characterization: isotopic data (N, S, O, C and Sr). Environ Sci Technol 38:3254-3262

Weil RR, Weismiller RA, Turner RS (1990) Nitrate contamination of groundwater under irrigated coastal plain soils. J Environ Qual 19:441-448

XLSTAT (2008) Data analysis and statistical solution for MS Excel, 2008. http://www.xlstat.com. Accessed 04 November 2008 